\title{
RANCANG BANGUN MESIN PENGADUK SABUN CUCI CAIR UNTUK MENGOPTIMALKAN WAKTU PRODUKSI PADA INDUSTRI RUMAH TANGGA
}

\author{
Rahmatul Ahya ${ }^{1}$, Rian Prasetyo ${ }^{2}$, Maria Puspita Sari ${ }^{3}$, Mathilda Sri Lestari ${ }^{4}$ \\ ${ }^{1}$ Program Studi Teknik Industri / Fakultas Teknik / Universitas Veteran Bangun Nusantara / \\ Rahmatulahya70@gmail.com \\ ${ }^{2}$ Program Studi Teknik Industri / Fakultas Teknik / Universitas Veteran Bangun Nusantara / \\ rnprasetyo286@gmail.com \\ ${ }^{3}$ Program Studi Teknik Industri / Fakultas Teknik / Universitas Veteran Bangun Nusantara / \\ maria_puspita_1989@yahoo.com \\ ${ }^{4}$ Program Studi Teknik Industri / Fakultas Teknik / Universitas Veteran Bangun Nusantara / \\ mathildasrilestari@yahoo.com
}

\begin{abstract}
Indonesia's economy during the second quarter of 2020 getting a contraction about 4.19 percent, due to the COVID-19 pandemic. This decline has an impact on the economic sector, one of which is MSMEs which contribute 15.75 percent annually to economic growth. Liquid soap is one of the MSMEs products that needs improvement because of this impact. This research was purposed to develop the process of mixing liquid soap ingredients with an electric-powered stirrer machine to obtain a constant mixing process, and produce a homogeneous mixture of liquid soap. The methods used in this research include manual process benchmarking, machine planing and design, testing, then results analysis. The results of this research succeeded in making a liquid soap mixer machine using " $L$ " shape plate frame with dimensions of length $x$ width $x$ height about $610 \times 530 \times 900 \mathrm{~mm}$. The power of the stirrer machine about $0.25 \mathrm{HP}$ using an electric motor, with rotation speed of $1400 \mathrm{rpm}$ on electric motor and $343.4 \mathrm{rpm}$ on stirrer, and produces a torque for stirring the concentrate of liquid soap about 3.42 N.m. The results of the production of liquid soap with the machine show an increased in production time about 30.9\%, and the product have characteristics of a thicker liquid soap, than manual production, for the same production volume.
\end{abstract}

Keywords : Liquid soap, Liquid soap mixing machine, Home industry, MSMEs

\begin{abstract}
ABSTRAK
Ekonomi indonesia selama triwulan II 2020 mengalami kontraksi mencapai 4,19 persen, akibat pandemi COVID-19. Penurunan tersebut berdampak pada sektor ekonomi, salah satunya pada UMKM yang memberikan kontribusi sebesar 15,75 persen setiap tahun terhadap pertumbuhan ekonomi. Sabun cuci cair merupakan salah satu produk UMKM yang perlu mendapat perhatian karena dampak tersebut. Penelitian ini dilakukan untuk melakukan pengembangan proses pencampuran bahan sabun cuci cair dengan mesin pengaduk bertenaga listrik untuk mendapatkan proses pencampuran yang konstan, dan menghasilkan campuran yang homogen. Metode yang digunakan dalam penelitian meliputi, benchmarking proses manual, perhitungan dan perancangan mesin, Ujicoba, lalu diakhiri dengan analisa hasil penelitian. Hasil penelitian berhasil membuat mesin pengaduk sabun cair dengan menggunakan rangka plat siku berdimensi panjang x lebar x tinggi sebesar 610 × 530 × $900 \mathrm{~mm}$. Daya mesin pengaduk menggunakan motor listrik 0,25 HP dengan kecepatan putaran pada motor listrik $1400 \mathrm{rpm}$ dan pada pengaduk $343,4 \mathrm{rpm}$, serta menghasilkan torsi untuk mengaduk konsentrat bahan baku sabun cair sebesar 3,42 N.m. Hasil produksi sabun cair dengan mesin menunjukkan waktu yang lebih cepat sebesar $30,9 \%$, dan memiliki karakteristik sabun cair yang lebih kental. apabila dibandingkan produksi secara manual, untuk volume produksi yang sama.
\end{abstract}

Kata Kunci : Sabun cair, Mesin pengaduk sabun cair, Industri rumah tangga, UMKM 


\section{PENDAHULUAN}

Ekonomi indonesia selama triwulan II 2020 mengalami kontraksi mencapai 4,19 persen. Penurunan yang terjadi tersebut disebabkan akibat pandemi Corona Virus Disease (COVID-19), yang menjadi faktor utama. Masalah kesehatan tersebut kemudian menciptakan efek domino yang merambat pada sektor sosial dan ekonomi, sehingga berdampak pada rumah tangga, UMKM, hingga tingkat industri besar. Berdasarkan data, dimana 63,9 persen para pelaku usaha mengalami penurunan omzet usaha lebih dari 30\% (Soleha, 2020).

Sejauh ini, UMKM memegang peran yang sangat penting, sebagai penggerak ekonomi indonesia. UMKM memberikan kontribusi terhadap pertumbuhan ekonomi di Indonesia pada rentang tahun 2007 sampai 2012 rata-rata sebesar 15,75 persen setiap tahunnya (Hapsari et al., 2014). Menurut Hamzah (2019), tenaga kerja dan investasi pada UMKM memiliki pengaruh yang positif dan signifikan terhadap pendapatan secara nasional. Hal tersebut menunjukkan pentingnya membangkitkan kembali serta mengembangkan UMKM di Indonesia, yang saat ini tengah dilanda penurunan sebagai dampak dari pandemi COVID-19, sehingga sektor UMKM dapat kembali mendorong pertumbuhan ekonomi di Indonesia.

Produksi pembuatan sabun cuci cair merupakan salah satu UMKM yang masih dapat dikembangkan. Sabun dihasilkan dari hidrolisa asam lemak dan basa. Sabun akan mencuci bagian yang kotor dengan reaksi kimia dari bahan tersebut (Sari et al., 2010). Menurut Salamah et al. (2018), sabun dapat digolongkan menjadi sabun yang teribuat dari asam lemak (sabun padat dan krim), dan yang terbuat dari zat anionik (sabun cair). Sabun cuci cair tersebut juga merupakan pengembangan dari jenis sabun cuci sebelumnya yang berupa sabun cuci bubuk dan sabun colek. Proses produksi dari sabun cair tersebut saat ini sebagian besar masih secara manual untuk proses pencampuran bahan-bahannya, terutama pada industri rumahan. Selain itu proses pencampuran bahan baku sabun cair secara manual, akan tidak optimal, karena secara proses pencampuran bahan, membutuhkan penambahan air secara bertahap, sehingga volume bahan yang dicampur semakin meningkat dan bertambah berat, akan tetapi tenaga yang dikeluarkan oleh manusia akan semakin menurun karena faktor keletihan. Juga dibutuhkan pengadukan yang konstan agar homogenitas sabun cair dapat optimal.

Perancangan alat merupakan proses penuangan ide dan gagasan berdasarkan teori-teori dasar yang mendukung pada alat yang kan digunakan (Gunawan, 2017). Penelitian terkait proses pembuatan mesin pengaduk sabun cair telah dilakukan oleh beberapa peneliti. Haryono (2018) dan Serarawani (2020), melakukan penelitian untuk pembuatan mesin pengaduk sabun cair, berdasarkan kaidah ergonomi. Hasil penelitian menunjukkan mesin yang dibuat sudah sesuai dengan kaidah ergonomi, akan tetapi masih terdapat kendala pada waktu proses yang masih lama, sehingga perlu dikembangkan penelitian untuk mengoptimalkan waktu proses pembuatan sabun cair dengan mesin pengaduk.

Penelitian lainnya pernah dilakukan oleh Amiludin (2014) dan Aris (2013), yang menunjukkan bahwa dengan penggunaan pengaduk yang tepat, dapat mempengaruhi hasil pembuatan sabun cair menjadi lebih baik. Akan tetapi penelitian ini masih belum memperhitungkan kapasitas mesin pengaduk yang dibuat juga optimalisasi waktu standar berdasarkan kapasitas mesin tersebut, pada industri rumah tangga. Hal ini dapat menjadi acuan untuk keperluan pengembangan mesin pengaduk sabun cair dengan kapasitas yang tepat dengan industri rumah tangga dan dapat mengoptimalkan proses produksi sabun cair tersebut.

Berdasarkan rincian diatas menunjukkan perlu dilakukan pengembangan proses produksi sabun cuci cair yang merupakan salah satu UMKM di Indonesia. Oleh karena itu, penelitian ini dilakukan untuk melakukan pengembangan proses pencampuran bahan sabun cuci cair dengan 
mesin pengaduk bertenaga listrik. Penggunaan mesin pengaduk ini ditujukan untuk mendapatkan proses pencampuran yang konstan, dan menghasilkan campuran yang homogen. Selain itu juga dapat mengoptimalkan waktu proses pembuatan sabun cair dengan kapasitas produksi didasarkan dari UMKM yang memproduksi sabun cair tersebut.

\section{METODE PENELITIAN}

\subsection{Benchmarking Proses Manual Pembuatan Sabun Cair}

Tahap ini dilakukan dengan mendatangi salah satu UMKM yang melakukan produksi pembuatan sabun cair secara manual. Pengamatan dilakukan mulai dari jenis sabun cair yang dibuat, dan proses produksi, terutama saat proses pengadukan. Proses pengadukan yang dilakukan secara manual ini kemudian diambil beberapa data untuk merancang mesin yang akan dibuat. Data yang diambil berupa waktu proses pengadukan, kapasitas, dan pengamatan homogenitas sabun cair yang dihasilkan.

\subsection{Perhitungan Kebutuhan Mesin}

Kebutuhan mesin dalam penelitian ini didasarkan oleh proses pengadukan sabun cair secara manual yang telah diamati. Tahap ini peneliti akan menghitung kebutuhan rangka mesin, motor penggerak, transmisi, dan kapasitas mesin yang akan dibuat. Hal ini ditujukan untuk mendapatkan perhitungan mesin yang tepat sesuai dengan proses manual dari pengadukan sabun cair tersebut.

\subsection{Perancangan Mesin dengan Software Autodesk Inventor}

Tahap ini dilakukan perancangan mesin secara keseluruhan dengan Software Autodesk Inventor. Penggambaran dilakuan pada tahap ini, sesuai perhitungan dimensi mesin yang telah dilakukan sebelumnya. Hasil dari tahap ini berupa gambar kerja sebagai acuan pembuatan mesin pengaduk sabun cuci cair ini.

\subsection{Ujicoba Mesin}

Tahap ini peneliti melakukan ujicoba proses pengadukan sabun cair. Ujicoba dilakukan dengan mesin pengaduk sabun cair yang telah dibuat. tahap ini peneliti mengambil data hasil produksi. Data yang akan diambil berupa putaran mesin, torsi, dan waktu produksi dengan mesin tersebut.

\subsection{Analisa Hasil}

Analisa hasil yang dilakukan berdasarkan data yang telah diambil. Dalam hal ini data produksi akan dibandingkan antara proses pengadukan manual dengan proses pengadukan mesin. Dari data tersebut akan dilakukan peningkatan efisiensi produksi dengan mesin, sehingga akan didapatkan mesin yang memberi nilai tambah untuk produksi sabun cair tersebut.

\section{HASIL DAN PEMBAHASAN}

\subsection{Pembuatan Sabun Cair Secara Manual}

Pembuatan sabun cair melibatkan proses pencampuran bahan baku dengan air pada wadah, lalu diaduk sampai homogen. Sabun cair untuk cuci pakaian dan cuci piring memiliki proses pencampuran yang sama. Bahan baku berupa konsentrat yang berfungsi sebagai pengikat kotoran, seperti yang terlihat pada Gambar 1. Air yang digunakan merupakan air bersih sebagai pelarut bahan baku sabun cair tersebut. 


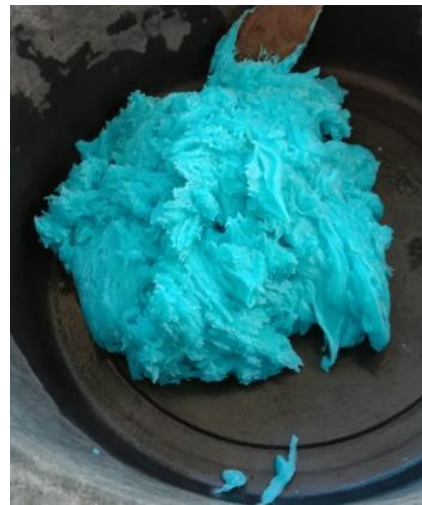

Gambar 1. Bahan baku sabun cair

Berdasarkan pengambilan data dengan cara pengamatan proses pencampuran bahan baku sabun cair dengan air, dapat diketahui data dan tahapan proses, untuk memcdapatkan hasil akhir sabun cair. Proses pencampuran secara manual ini dilakukan untuk kapasitas produksi sebesar 25 liter. Proses pengadukan yang dilakukan bisa dilihat pada Gambar 4.2. Jumlah tersebut terdiri dari 22 liter air dan sisanya adalah jumlah konsentrat bahan baku sabun cair. Air yang ditambahkan pada proses ini secara bertahap, masing-masing 1 liter. Setiap kali penambahan air dilakukan pengadukan secara konstan agar air dan konsentrat dapat tercampur secara maksimal. Tahap akhir pengadukan dilakukan lebih lama, sampai komposisi konsentrat dan air benar-benar homogen. Ini bisa dilihat dari tidak terdapatnya bulir-bulir konsentrat yang belum larut pada sabun cair tersebut. Untuk produksi dengan tonase 25 liter sabun cair ini berdasarkan hasil pengamatan, dibutuhkan waktu pengadukan 17,32 menit, sehingga proses produksi per liternya dibutuhkan waktu 0,69 menit.

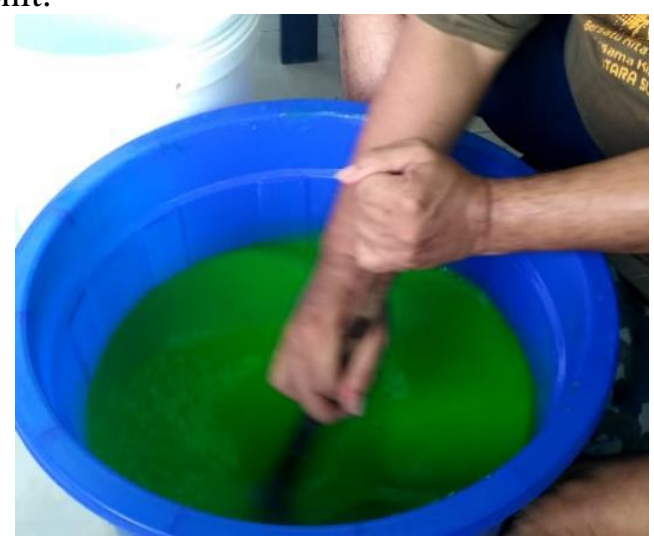

\section{Gambar 2. Proses pengadukan sabun cair secara manual}

\subsection{Perhitungan Kebutuhan Mesin}

Perhitungan kebutuhan mesin didasarkan pada proses pengadukan sabun cair. Mesin dirancang berdasarkan dimensi dan kekuatan putaran untuk melakukan proses pengadukan konsentrat dengan air. Untuk lebih detail dari perhitungan ini bisa dilihat dari perhitungan dimensi dan kekuatan mesin berikut:

\subsubsection{Perhitungan rangka mesin}

Rangka mesin merupakan salah satu komponen utama dari mesin pengaduk sabun cair yang akan dikembangkan. Rangka mesin dibuat menggunakan plat siku ukuran 40 x $40 \mathrm{~mm}$. Dimensi dari rangka mesin didasarkan pada ukuran bak yang digunakan untuk tempat pengadukan bahan baku sabun cair, dan ukuran motor listrik yang digunakan.

Tahap pertama dari perhitungan rangka ini adalah dilakukan pengukuran dimensi bak. Bentuk bak yang digunakan adalah kerucut terpancung. Kapasitas dari bak tersebut untuk memproduksi sabun cair adalah 40 liter. Pengukuran terhadap bak diasarkan pada beberapa bagian, antara lain, 
diameter atas bak, untuk menentukan panjang dan lebar rangka, tinggi bak, untuk menentukan jarak dudukan bak terhadap klem bagian atas bak, dan diameter bawah bak, untuk menentukan ukuran dudukan bak pada rangka. Hasil pengukuran dari bak tersebut dapat dilihat pada Tabel 1 .

Tabel 1. Dimensi bak pada mesin pengaduk sabun cair

\begin{tabular}{lc}
\hline \multicolumn{1}{c}{ Bagian bak } & Dimensi $(\mathbf{m m})$ \\
\hline Diameter atas & 520 \\
\hline Tinggi & 280 \\
\hline Diameter bawah & 400
\end{tabular}

Tahap selanjutnya adalah pengukuran dimensi motor listrik. Dimensi yang diukur adalah pada jarak antar lubang dari standing motor listrik tersebut. Jarak tersebut akan menentukan ketinggian rangka pada bagian atas mesin. Hal ini memberikan jarak aman dari permukaan cairan sabun cair terhadap transmisi yang akan digunakan dari mesin tersebut. Jarak antar lubang horizontal pada bagian standing motor berdasarkan hasil pengukuran adalah $200 \mathrm{~mm}$ dan untuk vertikal adalah $200 \mathrm{~mm}$.

\subsubsection{Perhitungan transmisi dan daya mesin}

Perhitungan pada bagian daya mesin didasarkan pada motor listrik yang digunakan pada mesin pengaduk sabun cair. Motor listrik yang digunakan memiliki daya 0,25 HP dengan putaran rotornya mampu mencapai $1400 \mathrm{rpm}$. Motor tersebut dipilih, karena ketersediaannya di lapangan cukup banyak, sehingga untuk pengadaannya cukup mudah. Berdasarkan spesifikasi tersebut diperoleh perhitungan torsi yang dihasilkan oleh motor listrik sebagai berikut:

$\tau=\frac{5252 \times \mathrm{P}}{\mathrm{N}}$ (Agussationo, 2021)

$$
\begin{aligned}
& =\frac{5252 \times 0,25}{1400} \\
& =0,94 \mathrm{~N} . \mathrm{m}
\end{aligned}
$$

Mesin yang dirancang pada penelitian ini menggunakan dua buah pulley sebagai transmisi, dengan perbandingan diameter 1:4. Pulley dengan diameter yang lebih kecil dipasang pada poros motor listrik, dan pulley dengan diameter lebih besar dipasang pada poros pengaduk, yang keduanya dihubungkan oleh $v$-rope belt. Hal tersebut didasarkan pada penelitian sebelumnya yang dilakukan oleh Zuber (2010). Berdasarkan rasio perbandingan transmisi tersebut didapatkan dua buah pulley dengan ukuran masing-masing $\varnothing 65 \mathrm{~mm}$ dan $\varnothing 265 \mathrm{~mm}$. Pertimbangan pemilihan masing-masing ukuran diameter pulley tersebut adalah ketersediannya di pasaran. Berdasarkan dua pulley yang digunakan untuk transmisi mesin pengaduk dapat dihitung kecepatan putaran pada poros pengaduk sebagai berikut:

$$
\begin{aligned}
\mathrm{N} 2 & =\frac{\mathrm{N} 1 \times \mathrm{D} 1}{\mathrm{D} 2} \text { (Istiqlaliyah, 2011) } \\
& =\frac{1400 \times 65}{265} \\
& =343,4 \mathrm{rpm}
\end{aligned}
$$

Berdasarkan hasil perhitungan kecepatan putaran pada poros pengaduk, dapat dihitung torsi yang dihasilkan oleh putaran poros pengaduk sebagai berikut:

$$
\begin{aligned}
\tau & =\frac{5252 \times \mathrm{P}}{\mathrm{N}}(\text { Agussationo, 2021) } \\
& =\frac{5252 \times 0,25}{343,4} \\
& =3,42 \mathrm{~N} . \mathrm{m}
\end{aligned}
$$

\subsection{Perancangan rangka mesin}

Perancangan rangka mesin ini dilakukan menggunakan software Autodesk Inventor 2013. Proses perancangan dilakukan di laboratorium komputer, Program Studi Teknik Industri, Universitas Veteran Bangun Nusantara. Dimensi dari rangka mesin yang dirancang berdasarkan ukuran bak dan standing motor listrik yang telah dilakukan pengukuran sebelumnya. Hasil dari pembuatan rancangan desain rangka mesin pengaduk dapat dilihat pada Gambar 3. 

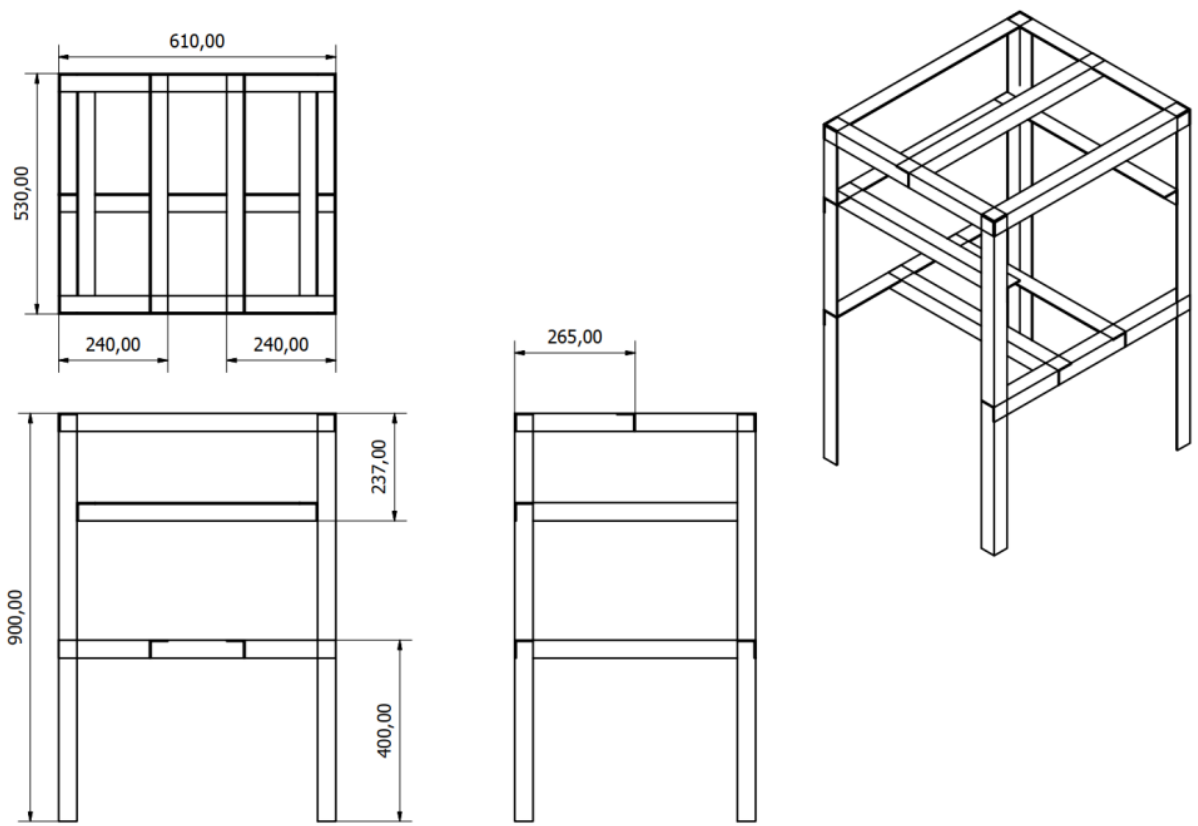

Gambar 3. Desain rangka mesin pengaduk sabun cair

Berdasarkan Gambar 3 dapat dilihat dimensi panjang dan lebar rangka, masing-masing $530 \mathrm{~mm}$ dan $610 \mathrm{~mm}$. Ukuran 530 didasarkan pada diameter atas dari bak dengan ditambahkan allowence. Ukuran 610 juga didasarkan pada diameter atas dari bak, ditambah dengan lebar kaki dari rangka tersebut pada masing-masing sisinya. Bagian atas rangka dirancang dudukan poros pengaduk dengan jarak $265 \mathrm{~mm}$ dari bagian depan. Dudukan tersebut disesuaikan agar tepat ditengah-tengah ember agar pengaduk dapat mengaduk sabun cair secara sentral. Bagian belakang dari rangka dirancang dudukan motor dengan lebar $237 \mathrm{~mm}$. hal ini disesuaikan dengan jarak antar lubang pada standing motor listrik yang sebelumnya telah dilakukan pengukuran. Bagian tengah dari rancangan juga terdapat plat siku dengan jarak masing-masing dari samping sebesar $240 \mathrm{~mm}$. Plat tersebut digunakan sebagai dudukan bak dengan disesuaikan pada diameter bawah dari bak tersebut. Ketinggian rancangan rangka mesin adalah $900 \mathrm{~mm}$.

\subsection{Perancangan Pengaduk}

Pengaduk yang dibuat dalam penelitian ini menggunakan bahan stainless steel pejal dengan $\varnothing$ $10 \mathrm{~mm}$. Pemilihan bahan tersebut ditujukan agar pengaduk lebih tahan korosif karena kontak dengan sabun cair. Dimensi pengaduk ini memiliki desain dengan panjang total $600 \mathrm{~mm}$ dan lebar $\mathrm{x}$ tinggi $=200 \times 200 \mathrm{~mm}$. Bentuk pengaduk dirancang mirip dengan pengaduk mixer adonan kue, karena memiliki fungsi (sebagai pengaduk) dan konsentrat yang hampir sama. Untuk lebih detail mengenai bentuk dan ukuran pengaduk tersebut dapat dilihat pada Gambar 4. 
Jurnal Inkofar * Volume 5 No. 1, Juli 2021 * E-ISSN: 2581-2920

Tersedia secara online di: http://www.politeknikmeta.ac.id/meta/ojs/

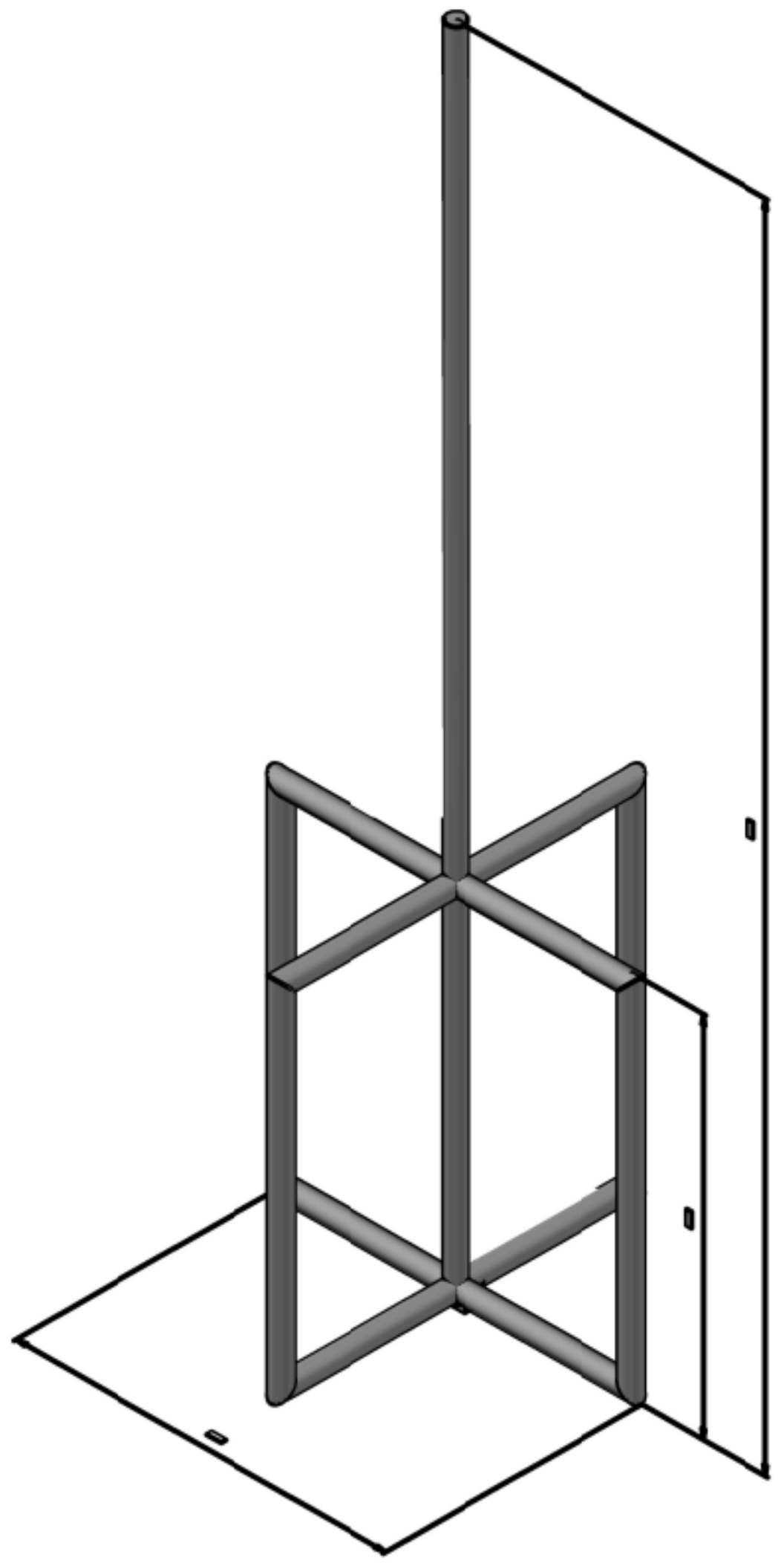

Gambar 4. Pengaduk sabun cair 


\subsection{Uji coba produksi sabun cair}

Setelah mesin selesai dibuat selanjutnya dilakukan uji coba produksi sabun cair dengan mesin tersebut. Uji coba dilakukan pada produksi sabun cair untuk cuci piring. Hal ini berdasarkan pertimbangan sabun cair untuk cuci piring dan cuci pakaian memiliki karakteristik yang hampir sama, sehingga dapat diasumsikan memiliki waktu produksi yang sama. Mesin pengaduk yang telah dibuat dapat dilihat pada Gambar 5.

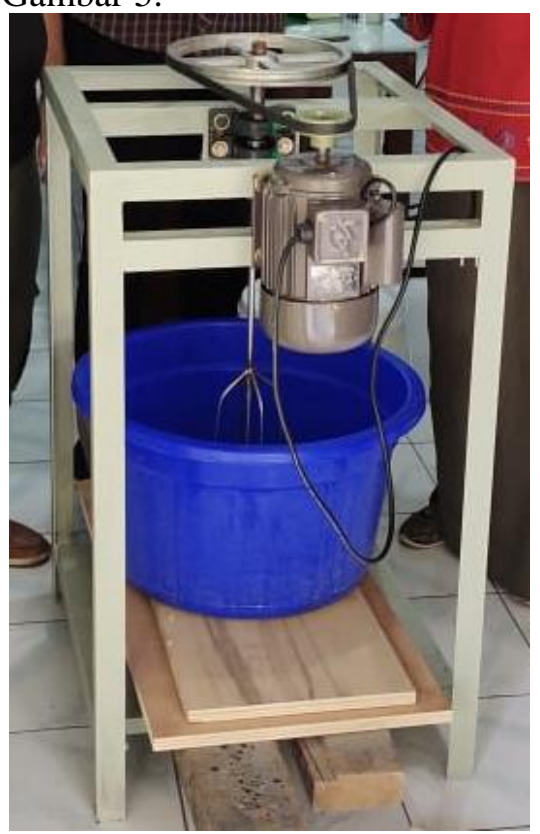

\section{Gambar 5. Mesin pengaduk sabun cair}

Uji coba dilakukan untuk produksi 25 liter sabun cair. Bahan baku yang digunakan berupa konsentrat dengan tonase $5 \mathrm{~kg}$. untuk memenuhi sampai dengan 40 liter, konsentrat tersebut dicampur dengan air destilasi sebanyak 22 liter.

Tahapan produksi dengan mesin ini berdasarkan proses pembuatan yang dilakukan secara manual. Pertama semua bahan baku dimasukkan pada bak yang tersedia. Selanjutnya dilakukan penambahan air secara bertahap sebanyak 1 liter. Untuk produksi sabun cair dengan mesin, proses penambahan air harus dilakukan lebih cepat. Hal ini dikarenakan proses pengadukan dengan mesin lebih cepat daripada manual.

Proses pengadukan dengan mesin, menghasilkan homogenitas bahan baku dengan air, dengan air kurang bagus. Hal ini dikarenakan desain pengaduk dari mesin tersebut kurang dapat mengangkat bahan baku yang memiliki berat jenis lebih tinggi daripada air, sehingga masih terdapat sedikit bahan baku pada dasar bak. Hal tersebut dapat ditanggulangi dengan menerapkan proses pengadukan secara manual untuk mengangkat bahan baku yang terdapat pada dasar bak. Lalu dilanjutkan kembali proses pengadukannya dengan mesin. Operation Process Chart dalam pembuatan sabun cair ini dapat dilihat pada Gambar 6. Hasil produksi sabun cair dengan mesin, dapat dilihat pada Gambar 7. 


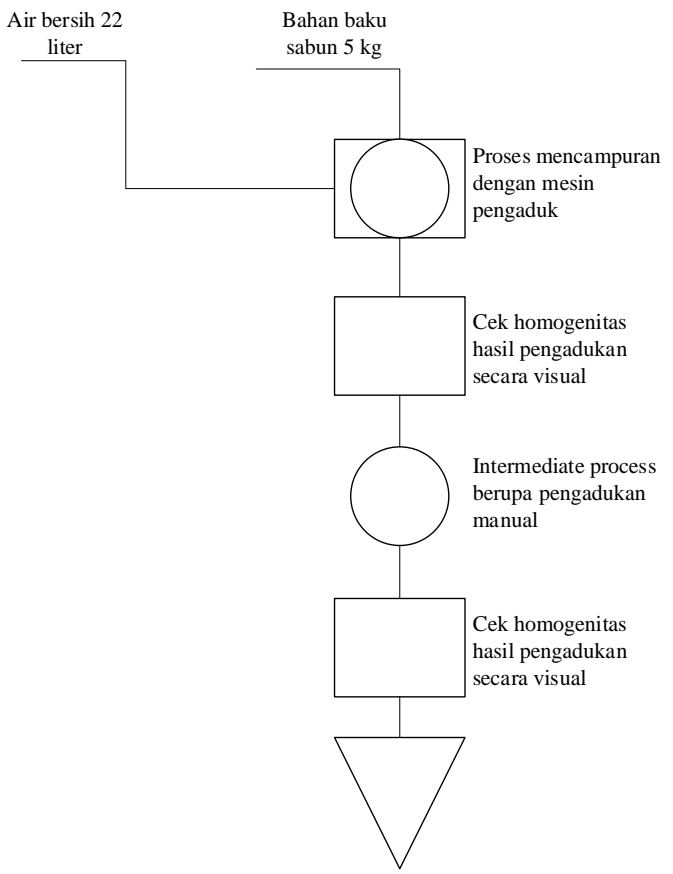

\section{Gambar 6. Operation Process Chart pembuatan sabun cair}

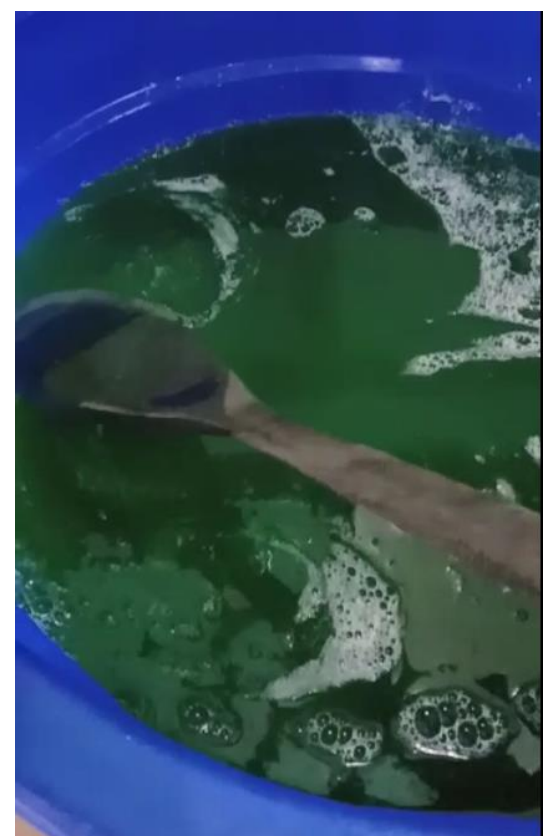

\section{Gambar 7. Hasil produksi sabun cair dengan mesin}

Total waktu produksi dengan mesin adalah 12,11 menit. Waktu tersebut sudah termasuk pengadukan secara manual, sebagai intermediate process, selama 5,5 menit. Berdasarkan rasio waktu produksi terhadap tonase produksi pada proses pembuatan sabun cair dengan mesin ini didapatkan rate produksi sebesar 0,55 menit untuk setiap liter sabun cair. Hal tersebut menunjukkan waktu produksi dengan mesin lebih cepat 30,1\% dibandingkan produksi secara manual untuk volume produksi yang sama. Selain itu berdasarkan pengamatan tehadap hasil produksi sabun cair dengan mesin, didapatkan karakteristik sabun cair yang lebih kental, yang berarti menunjukkan bahan baku sabun cair dapat tercampur dengan baik. Hal ini dikarenakan pada proses pembuatan sabun cair dengan mesin memiliki kecepatan putaran pengadukan yang lebih tinggi dan lebih konstan, apabila dibandingkan dengan manual. Selain itu juga dilakukan intermediate process, yang menambah tingkat homogenitas sabun cair menjadi lebih baik. 


\section{KESIMPULAN}

Berdasarkan hasil penelitian yang telah dilakukan, dihasilkan mesin pengaduk sabun cair, untuk kapasitas produksi 25 liter, dengan rangka plat siku. Dimensi panjang x lebar x tinggi sebesar $610 \times 530$ × $900 \mathrm{~mm}$. Daya mesin pengaduk menggunakan motor listrik 0,25 HP dengan kecepatan putaran pada motor listrik $1400 \mathrm{rpm}$ dan pada pengaduk 343,4 rpm, serta menghasilkan torsi untuk mengaduk konsentrat bahan baku sabun cair sebesar 3,42 N.m. Hasil produksi sabun cair dengan mesin menunjukkan waktu yang lebih cepat sebesar 30,9\%, dan memiliki karakteristik sabun cair yang lebih kental apabila dibandingkan produksi secara manual, untuk volume produksi yang sama.

Berdasarkan penelitian ini juga perlu dilakukan penelitian tersendiri untuk pembuatan jenis sabun yang lain, karena terdapat jenis sabun yang mungkin memiliki karakteristik yang berbeda dengan sabun cuci piring dan cuci pakaian. Perlu dilakukan penelitian mengenai bentuk pengaduk yang berbeda, untuk meningkatkan homogenitas bahan baku sabun cair dengan air, sehingga didapatkan hasil produksi sabun cair dengan mesin secara optimal.

\section{DAFTAR PUSTAKA}

Agussationo, Y. (2021). Peningkatan Kinerja Motor Induksi Melalui Variasi Diameter Lilitan Kawat. Jurnal Elektronika, Listrik, Dan Teknologi Informasi Terapan, 2(2), 8-14. https://doi.org/10.37338/e.v2i2.148

Amiludin, N. H. (2014). Analisa Rancang Bangun Mesin Pengaduk Bahan Baku Sabun Mandi Cair. Jurnal Rekayasa Mesin, 1(2), 35-40.

Aris, E. (2013). Pengaruh Jenis Pengaduk Helical-Ribbon, dan Dayung (Paddle) Terhadap Hasil Produk Sabun Cuci Cair. Jurnal Teknik Mesin, 01(2), 336-343.

Gunawan, R. (2017). Perancangan Alat dan Sistem Smart Charger pada Smart. In Universitas Islam Negeri Alauddin Makassar. https://doi.org/10.1017/CBO9781107415324.004

Hamzah, M. (2019). Pengaruh Perkembangan Usaha Mikro , Kecil , dan Menengah Terhadap Pendapatan Nasional Pada Sektor UMKM di Indonesia. Jurnal Ekonomi Pembangunan, $8(2), 127-135$.

Hapsari, P. P., Hakim, A., \& Soeaidy, S. (2014). Pengaruh Pertumbuhan Usaha Kecil Menengah ( UKM ) terhadap Pertumbuhan Ekonomi Daerah ( Studi di Pemerintah Kota Batu ). Jurnal Wacana, 17(2), 88-96.

Haryono. (2018). Perancangan Alat Pengaduk Sabun Cair Berdasarkan Kaidah Ergonomi. Institut Teknologi Nasional Malang.

Istiqlaliyah, H. (2011). Perencanaan Mesin Peniris Minyak Pada Keripik Nangka Dengan Kapasitas 2, $5 \mathrm{Kg} /$ Menit. Nusantara of Engineering, 2(1), 37-43.

Salamah, S., Sulistiawati, E., \& Aktawan, A. (2018). Pelatihan Teknologi Kimia Terapan Pembuatan Sabun Cair Cuci Piring, Sabun Mandi Herbal Dan Tepung Ampas Kelapa IbuIbu 'Aisyiyah Ranting Perumnas Condong Catur, Depok, Sleman. Jurnal Pemberdayaan: Publikasi Hasil Pengabdian Kepada Masyarakat, 1(2), 465. https://doi.org/10.12928/jp.v1i2.326

Sari, T. I., Kasih, J. P., Jayanti, T., \& Sari, N. (2010). Pembuatan Sabun Padat dan Sabun Cair dari Minyak Jarak. Jurnal Teknik Kimia, 17(1), 28-33.

Serarawani, P. N. (2020). Pengembangan Perancangan Alat Mixing Sabun Cair yang Sesuai Kaidah Ergonomi. Valtech (Jurnal MahasiswaTeknik Industri), 3(1), 75-83.

Soleha, A. R. (2020). Kondisi UMKM Masa Pandemi Covid-19 pada Pertumbuhan Ekonomi Krisis Serta Program Pemulihan Ekonomi Nasional. Jurnal Ekombis, 6(2), 165-178. 